\title{
Masquerade uveitis with hypopyon as a solitary feature of relapsed leukaemia in a child
}

\author{
Teena Mariet Mendonca (D) ,', Harsha Prasada Lashkari, ${ }^{2,3}$ Jyoti Kini, ${ }^{2,4}$ \\ Tishya Vepakomma ${ }^{1,2}$
}

${ }^{1}$ Ophthalmology, Kasturba Medical College Mangalore, Mangalore, Karnataka, India ${ }^{2}$ Manipal Academy of Higher Education, Manipal, Karnataka, India

${ }^{3}$ Division of Pediatric Hematology/Oncology, Kasturba Medical College Mangalore, Mangalore, Karnataka, India ${ }^{4}$ Pathology, Kasturba Medical College Mangalore, Mangalore, Karnataka, India

\section{Correspondence to}

Dr Teena Mariet Mendonca; tmendonca87@gmail.com

Accepted 6 May 2021

Check for updates

(c) BMJ Publishing Group Limited 2021. No commercial re-use. See rights and permissions. Published by BMJ.

To cite: Mendonca TM, Lashkari HP, Kini J, et al. BMJ Case Rep 2021:14:e240485. doi:10.1136/bcr-2020240485

\section{DESCRIPTION}

A 5-year-old boy presented with redness and watering in his left eye for 3 days. The child was on treatment for pre B-cell acute lymphoblastic leukaemia (ALL). At the time of diagnosis of ALL, he had presented to the hospital with fever for 2 weeks' duration and found to have hepatosplenomegaly with thrombocytopenia. Bone marrow studies and Cerebrospinal fluid (CSF) analysis confirmed the diagnosis of ALL with central nervous system (CNS) involvement and he received two consecutive weekly intrathecal methotrexate doses. He was started on treatment as per regimen A (three drug induction) of UKALL 2003 protocol. $^{1}$ At the end of induction, bone marrow analysis was consistent with disease remission with minimal residual disease $<0.01 \%$ suggestive of standard risk. At the time of presentation to us, the child had just completed delayed intensification phase and started on first maintenance cycle of treatment. On ophthalmologic evaluation, the best-corrected visual acuity was $20 / 20$ in the right eye and 20/200 in the left eye. Anterior segment examination revealed circum-corneal congestion in the left eye, anterior chamber cells $4+$ with white hypopyon measuring around $2 \mathrm{~mm}$ in height (figure 1$){ }^{2}$ The pupil was meiotic, pupillary reaction was sluggish. Lenticular opacity was present in the posterior subcapsular region. Intraocular pressure was raised to $28 \mathrm{~mm} \mathrm{Hg}$. Ultrasound $\mathrm{B}$-scan showed choroidal thickening and exudative retinal detachment. CSF analysis and bone marrow aspiration were negative for leukaemic cells. Anterior chamber paracentesis revealed atypical lymphoid cells suggestive of leukaemic infiltration (figure 2). Anterior uveitis with hypopyon in the left eye was the sole clinical feature suggestive of relapse of ALL in this child. Reinduction treatment as per ALL R3 protocol was started following which, ocular and cranial radiotherapy, as well as subsequent bone marrow transplant, was planned. Unfortunately, he succumbed to his illness during the reinduction phase within a couple of months after relapse was diagnosed.

ALL is a haematologic malignancy originating from haematopoietic cells of B-cell or T-cell lineage. Although it can affect children and adults, it predominantly affects children between the age of 1 and 4 years of age. ${ }^{3}$ Advances in modern diagnostic and treatment protocols have achieved nearly $80 \%-85 \%$ cure rate in children with ALL. ${ }^{4}$ Unfortunately, relapse occurs in $15 \%-20 \%$ of the cases. ${ }^{5}$ The most common sites for relapse are bone marrow, CNS and testis. ${ }^{4}$ Ocular relapse is

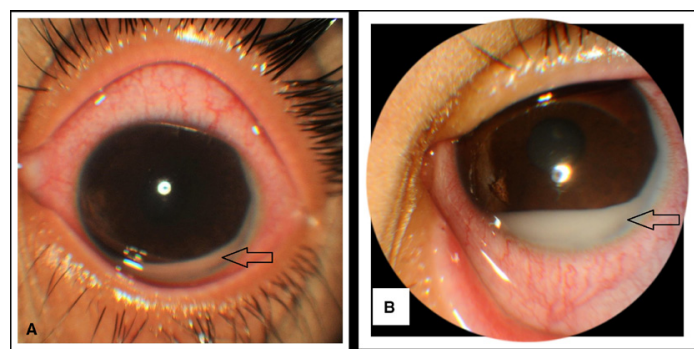

Figure 1 A clinical photograph $(A)$ and slit-lamp image (B) of the left eye showing white hypopyon (black arrow) measuring around $2 \mathrm{~mm}$ in height, the lateral border of which extends up to upper two-thirds of the temporal limbus.

rare, accounting for $0.5 \%-2.5 \%$ of the cases of leukaemic relapse. ${ }^{6-8}$ Ocular relapse can occur in isolation or along with relapse in bone marrow or CNS. ${ }^{4}$ Ophthalmic manifestations in patients with ALL can be a presenting sign of the malignancy or may indicate relapse of the disease. ${ }^{7}$ Iris and anterior chamber involvement is more often seen in ALL than chronic lymphoid leukaemia or myeloid leukaemia. ${ }^{9}$

Ophthalmic manifestations of leukaemia can occur due to three reasons. (1) Direct infiltration of ocular tissues such as iris, choroidal and optic nerve. (2) Haematological abnormalities causing leukaemic and anaemic retinopathy. (3) Neuroophthalmic signs such as papilloedema due to CNS

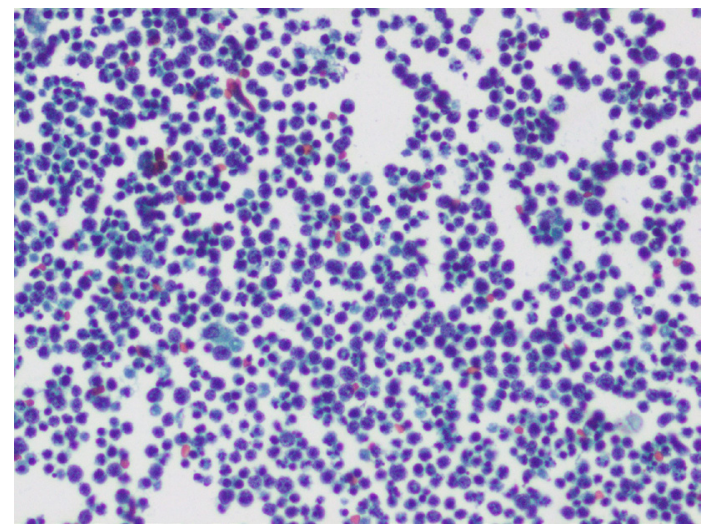

Figure 2 Anterior chamber aspirate cytology—high power view showing monomorphic population of lymphoblasts with high nuclear: cytoplasmic ratio, condensed coarse chromatin and scant cytoplasm $(\times 400$, Pap stain). 
involvement and raised intracranial tension. ${ }^{10} 11$ The presenting symptoms of anterior segment involvement could be redness, ocular pain, photophobia, watering and diminished vision. ${ }^{8}$ Occurrence of ocular inflammation in a patient with a history of leukaemia should raise suspicion of intraocular infiltration or relapse of leukaemia. Clinical signs of intraocular relapse or infiltration include, signs of anterior uveitis/iritis with or without hypopyon, iris nodules or thickening, pupillary abnormalities, secondary glaucoma, retinal/choroidal infiltrates and serous retinal detachments. ${ }^{8}$ These patients may be wrongly diagnosed to have 'atypical conjunctivitis' or 'uveitis' and more often treated with antibiotic and steroids. High index of clinical suspicion is necessary in such cases as the prognosis of ocular relapse in leukaemia is guarded and it requires aggressive local and systemic therapy.

The role of eye care professional is very important in diagnosis of masquerade uveitis in acute leukaemia. Ocular manifestations in leukaemia could be the first sign of the diagnosis or relapse of the disease following treatment. Since the management is challenging, and prognosis is poor after an ocular relapse, high index of suspicion and timely diagnosis is the key for a better outcome.

\section{Learning points}

- Iris and anterior segment involvement is more common with acute lymphoblastic leukaemia (ALL) than myeloid leukaemias.

- Ophthalmic manifestations in patients with ALL can be presenting sign of the malignancy or may indicate relapse of the disease.

Contributors TMM: Manuscript writing, concepts. HPL: Clinical management, manuscript editing. JK: Additional resources (pathology). TV: Manuscript editing.
Funding The authors have not declared a specific grant for this research from any funding agency in the public, commercial or not-for-profit sectors.

Disclaimer Case reports provide a valuable learning resource for the scientific community and can indicate areas of interest for future research. They should not be used in isolation to guide treatment choices or public health policy.

Competing interests None declared.

Patient consent for publication Parental/guardian consent obtained.

Provenance and peer review Not commissioned; externally peer reviewed.

ORCID iD

Teena Mariet Mendonca http://orcid.org/0000-0002-7297-386X

\section{REFERENCES}

1 Lashkari HP, Faheem M, Sridevi Hanaganahalli B, et al. Resource limited centres can deliver treatment for children with acute lymphoblastic leukaemia with risk-stratified minimal residual disease based UKALL 2003 protocol with no modification and a good outcome. Expert Rev Hematol 2020;13:1143-51.

2 Jabs DA, Nussenblatt RB, Rosenbaum JT, et al. Standardization of uveitis Nomenclature for reporting clinical data. Results of the first International workshop. Am J Ophthalmol 2005;140:509-16.

3 Malard F, Mohty M. Acute lymphoblastic leukaemia. Lancet 2020;395:1146-62.

4 Somervaille TCP, Hann IM, Harrison G, et al. Intraocular relapse of childhood acute lymphoblastic leukaemia. Br J Haemato/ 2003;121:280-6.

5 Hunger SP, Mullighan CG. Acute lymphoblastic leukemia in children. N Engl J Med 2015;373:1541-52.

6 MacLean $\mathrm{H}$, Clarke MP, Strong NP, et al. Primary ocular relapse in acute lymphoblastic leukemia. Eye 1996;10:719-22.

7 Yu AM, Chan SC, lordanous Y, et al. Anterior segment infiltration of acute lymphoblastic leukemia: case report and systematic review. Can J Ophthalmol 2019:54:20-6.

8 Novakovic P, Kellie SJ, Taylor D. Childhood leukaemia: relapse in the anterior segment of the eye. Br J Ophthalmol 1989;73:354-9.

9 Sharma T, Grewal J, Gupta S, et al. Ophthalmic manifestations of acute leukaemias: the ophthalmologist's role. Eye 2004;18:663-72.

10 Reddy SC, Menon BS. A prospective study of ocular manifestations in childhood acute leukaemia. Acta Ophthalmol Scand 1998;76:700-3.

11 Gillette TB, Cabrera MT, Tarlock K, et al. Rapidly progressive, isolated subretinal leukemic relapse: a case report. Ocul Oncol Pathol 2018;4:220-4.

Copyright 2021 BMJ Publishing Group. All rights reserved. For permission to reuse any of this content visit

https://www.bmj.com/company/products-services/rights-and-licensing/permissions/

BMJ Case Report Fellows may re-use this article for personal use and teaching without any further permission.

Become a Fellow of BMJ Case Reports today and you can:

- Submit as many cases as you like

- Enjoy fast sympathetic peer review and rapid publication of accepted articles

- Access all the published articles

- Re-use any of the published material for personal use and teaching without further permission

Customer Service

If you have any further queries about your subscription, please contact our customer services team on +44 (0) 2071111105 or via email at support@bmj.com.

Visit casereports.bmj.com for more articles like this and to become a Fellow 